\title{
Deer damage to alfalfa and mixtures with timothy or orchardgrass
}

\author{
MARVIN H. HALL AND ROBERT C. STOUT
}

Hall is an associate professor, Department of Agronomy; Stout is a project assistant, Department of Dairy and Animal Science, The Pennsylvania State University, University Park, Penn. 16802.

\begin{abstract}
White-tailed deer (Odocoileus virginianus L.) feed heavily on alfalfa (Medicago sativa L.) throughout Pennsylvania. Attempts to reduce deer feeding on forage crops have proven too costly or ineffective. The objective of this research was to determine the loss in yield and economic returns caused by deer feeding on pure and mixed stands of perennial forage crops. At 2 locations in central Pennsylvania, plots of pure alfalfa, timothy, and orchardgrass, and alfalfa-grass mixtures of 25,50 , and $75 \%$ alfalfa were established within areas protected (with fencing) or unprotected from deer. Forage was harvested and dry matter yields, percentage of alfalfa and grass, forage quality, and net economic returns were determined. Deer reduced forage dry matter (DM) yield by 1,451 $\mathrm{kg} \mathrm{ha}^{-1} \mathrm{yr}^{-1}$. Deer feeding also reduced annual yield of pure alfalfa by an average of $54 \%$, while yields of pure orchardgrass were reduced by only $7 \%$, resulting in average economic losses of $\$ 198$ and $\$ 59 \mathrm{ha}^{-1}$ for pure alfalfa and pure orchardgrass, respectively. Deer fed more on plots containing timothy than those containing orchardgrass. Forage quality was unaffected by deer feeding but declined as the proportion of alfalfa to grass in the mixture declined. In unprotected areas, mixtures seeded at $50 \%$ timothy or 25 to $75 \%$ orchardgrass produced greater economic returns than pure alfalfa.
\end{abstract}

Key Words: white-tailed deer, economics

Due to its relatively high nutritional value, alfalfa is a major component of dairy and livestock diets in Pennsylvania (Penn. Ag. Stats. Service 1997). However, white-tailed deer, which are native to Pennsylvania's woodlands, have adapted well to living among Pennsylvania's farmland and can cause considerable damage to alfalfa (English and Bramble 1949, Kosack 1996, Schumacher 1997, Shope 1970). Thomas (1954) reported that deer caused a 78\% yield reduction in alfalfa fields. Palmer et al. (1982) reported yield losses of $20 \%$ and economic losses of \$209 ha $^{-1}$ when deer fed in Pennsylvania alfalfa fields.

Various types of deterrents (e.g. fencing, spreading repellents such as fecal matter and urine of natural deer predators, and installing noise making devices in and around fields) have been used in an attempt to prevent deer damage to crops.

Manuscript accepted 14 Dec. 1998

\section{Resumen}

En Pennsilvania, el venado cola blanca (Odocoileus virginianus L.) se alimenta en gran parte de "Alfalfa" (Medicaco sativa $\mathbf{L}$.). Los intentos para reducir que los venados se alimenten de cultivos forrajeros han sido costosos e inefectivos. El objetivo de este estudio fue determinar las perdidas en rendimiento y retorno económico causado por la alimentación de los venados en poblaciones puras y mezcladas de cultivos forrajeros perennes. El estudio se condujo en 2 localidades de la parte central de Pennsilvania. Se establecieron parcelas de "Alfalfa", "Timothy" y "Orchardgrass" puros y parcelas de "Alfalfa" mezclada con un 25,50 y $75 \%$ de zacate. Se establecieron 2 grupos de parcelas, unas protegidas (cercadas) contra el venado y otras sin protección. Las parcelas se cosecharon y se determinó el rendimiento de materia seca, porcentaje de "Alfalfa" y zacate, calidad de forraje y el retorno neto económico. El venado redujo en $1,451 \mathrm{~kg} \mathrm{ha}^{-1} \mathrm{año}^{-1}$ el rendimiento anual de materia seca de forraje. La alimentación del venado también redujo en 54\% el rendimiento anual de la "Alfalfa " pura, mientras que el rendimiento del "Orchardgrass" puro se redujo solo un 7\%. En promedio, las perdidas económicas fueron del orden de $\$ 198$ y $\$ 59$ dólares ha ${ }^{-1}$ para "Alfalfa" pura y "Orchardgrass" puro respectivamente. El venado se alimento más en parcelas que contenían "Timothy" que en las que contenían "Orchardgrass". La calidad del forraje no fue afectada por la alimentación del venado, pero declino conforme la proporción de "Alfalfa" en la mezcla disminyo. En áreas sin protección las mezclas sembradas con $50 \%$ de "Timothy" o 25 a $50 \%$ de "Orchardgrass" produjeron mayores retornos económicos que la "Alfalfa" pura.

These attempts have been unsatisfactory because of high costs, ineffectiveness, or both (George et al. 1983, Andelt et al. 1991, Vecellio et al. 1994).

In a New Zealand study, deer preferred legumes over grasses (Hunt and Hay 1989). English and Bramble (1949), in a Pennsylvania study, reported that deer "are none discriminating except in choosing the best forage available". Also in Pennsylvania, Thomas (1954) observed that "...the deer would graze fields selectively by nipping the tops out of the clover and alfalfa plants, leaving the grasses unharmed." Thomas also noted that deer damage to pure legume hay was heavier than damage done to legume-grass mixed hay. Use of alternative forage species or forage mixtures to minimize deer feeding and economic loss is warranted. 
Failures in attempts to control deer feeding on alfalfa and reports that deer prefer legumes over grasses, prompted this research to test an agronomic solution to deer damage to forage crops. The objective of this research was to determine yield and economic losses associated with deer feeding on pure and mixed stands of perennial forage crops.

Forages were seeded during August 1994 into a Buchanan channery loam (fine-loamy, mixed, mexic Aquic Fraguidult) soil at 2 sites on the Russell E. Larson Agricultural Research Center near Rocksprings, Penn. $\left(40^{\circ} 48^{\prime} \mathrm{N}\right.$, $77^{\circ} 52^{\prime} \mathrm{W}$, Elev. $372 \mathrm{~m}$ ). Both sites, near wooded mountain ridges, were bordered by corn or alfalfa. Lime and soil nutrients were applied prior to seeding according to soil test recommendations to achieve optimum levels.

'Pioneer 5373' alfalfa, 'Toro' timothy (Pleum pratense L.), and 'Pennlate' orchardgrass (Dactylis glomerata L.) were seeded into 2 by $6.1 \mathrm{~m}$ plots to achieve pure stands of each species and mixed stands of 25,50 , and $75 \%$ alfalfa. Seeding mixtures were replicated 4 times in a split-plot arrangement of a randomized complete block design. Whole plots were contained within "deer proof" fence or left unfenced and accessible to deer for grazing. The deerproof fence consisted of 3 strands of electrified super-wide, positive-negative hot tape (Premier, Washington, Iowa) at 30,80 , and $135 \mathrm{~cm}$ heights charged with 6300 volts.

Plots were mechanically harvested in 1995 and 1996 when the alfalfa was in the early flower stage (Kalu and Fick 1981). Prior to mechanical harvesting, visual estimates of forage persistence were made and a hand-harvested sample was collected from a randomly selected $0.3 \mathrm{~m}$ strip across each plot to determine percent species composition. Approximately $1 \mathrm{~kg}$ of the mechanically harvested forage from each plot was oven dried at $60^{\circ} \mathrm{C}$ for 48 hours for dry matter (DM) determination and then ground to pass a $1 \mathrm{~mm}$ screen for quality analysis.

Quality analyses included crude protein content (CP, Kjeldahl N x 6.25), acid detergent fiber (ADF), and neutral detergent fiber (NDF) (Goering and Van Soest 1970) using Near-Infrared Reflectance Spectroscopy (NIRS). In 1995, 80 samples were selected from all harvested samples using the SELECT program described by Shenk and Westerhaus (1994) and analyzed chemically for CP, ADF, and NDF. These 80 samples were used to create a calibration equation to predict constituents of all samples collected in 1995. In 1996, 40 samples were selected using the SELECT program, chemically analyzed, and added to the NIRS prediction equation from 1995 to predict the quality of samples collected in 1996.

After each harvest, $33.6 \mathrm{~kg} \mathrm{ha}^{-1} \mathrm{~N}$ (ammonium nitrate) was applied to all plots. To control potato leafhopper (Empoasca fabae Harris), Dimethoate (0,0-dimethyl S-[N-methylcarbamoyl)methyl] phosphorodiathioate) insecticide was used as needed.

Economic comparison between treatments was based on the difference between the value of harvested forage and variable costs of production. Forage value was based on CP, and TDN (total digestible nutrients) content and yield relative to a reference forage with $\mathrm{CP}$, $\mathrm{TDN}$, and $\$ / \mathrm{Mg}$ (metric ton) values of $16 \%, 54 \%$, and $\$ 93.50$ respectively (Hall and Eckert 1992, Linn and Martin 1985). Cash values were established at which the forage nutrients above the reference forage level could be obtained by purchasing corn (Zea mays L.) grain and soybean (Glycine max L.) meal for sources of TDN and CP, respectively. Corn and soybean meal were priced at $\$ 0.11 \mathrm{~kg}^{-1}$ and $\$ 0.29 \mathrm{~kg}^{-1}$, respectively.

Variable costs of production were detected from revenue generated by each treatment to determine net economic return. Harvest costs were assessed at $\$ 69 \mathrm{ha}^{-1}$ per harvest (Hall and Marshall 1996) and fertilizer and insecticide costs were set at $\$ 37$ and $\$ 23.50 \mathrm{ha}^{-1}$ per application, respectively. Nitrogen and insecticide costs were not added to production costs for treatments with more than and less than $50 \%$ alfalfa, respectively, as these treatments would not normally receive nitrogen or insecticide.

Data from each location were analyzed initially as a split-plot arrangement of a randomized complete block design. The homogeneity of variance was tested and data were than analyzed over locations and years. Least significant difference values $(0.05)$ were calculated for statistical comparisons among treatments.

\section{Results and Discussion}

\section{Growth Environment}

In 1995 and 1996, precipitation was below and near normal, respectively. Although no method was used to definitively determine deer grazing pressure on the research sites, it was believed to be typical of grazing pressure throughout much of Pennsylvania. At times, as many as 7 deer were observed grazing the unprotected research area (about $0.08 \mathrm{ha}$ ).

\section{Forage Yield:}

Averaged over all unprotected treatments, deer consumed $1,451 \mathrm{~kg}$ of forages $\mathrm{ha}^{-1}$ (Fig. 1). Deer feeding reduced total yield of pure alfalfa treatments by $54 \%$ while total yields of pure orchardgrass treatments were reduced by only $7 \%$. Pure orchardgrass produced the greatest forage yield among unprotected plots. These yield reductions are greater than those previously reported by Palmer et al. (1982) but less than those reported by Thomas (1954). In the unprotected areas, all seeding mixtures and pure grass produced greater yields than pure alfalfa.

Deer selectivity grazed alfalfa out of the alfalfa-grass mixtures. Averaged over all protected plots, alfalfa constituted $35 \%$ of the total yield but in unprotected plots, alfalfa constituted only $19 \%$ of the total yield. This finding supports previous observations by Thomas (1954), and Hunt and Hay (1989) that deer prefer legumes over grasses in mixed stands.

Deer fed more in plots that contained timothy than those containing orchardgrass. Averaged over all unprotected plots containing timothy and orchardgrass, yields averaged 35 and $20 \%$ less, respectively, than their protected counterparts. This indicates that, in this study as in Thomas's (1954) work, timothy was more palatable to deer than orchardgrass.

\section{Forage Persistence and Weed Yield:}

Deer feeding resulted in lower forage persistence and an average of $1,199 \mathrm{~kg}$ $\mathrm{ha}^{-1}$ greater weed yield than in protected plots during the second year of the study (data not shown). Weed yields were greatest in the pure alfalfa plots and 


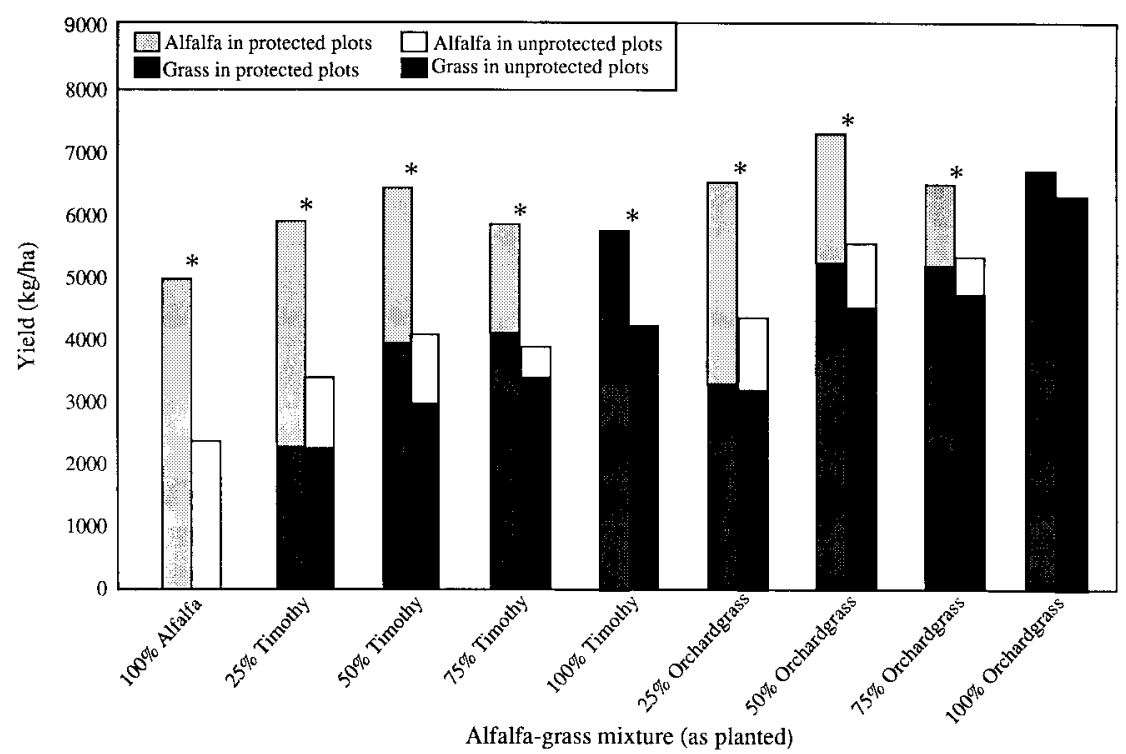

Fig. 1. Dry matter yield from pure stands and mixtures of alfalfa and timothy or orchardgrass that were protected or unprotected from deer feeding. Values are the mean of 2 locations over 2 years. Protected or unprotected means of total yield with an * are different at the 0.05 level. decreased as the amount of grass in the seeding mixture increased. The lowest weed yields were in the pure orchardgrass plots. Weed yields in the second year of the study were directly related $\left(\mathrm{R}^{2}=0.64 ; \mathrm{y}=86+2.15 \mathrm{X}\right)$ to the reduction in forage yield caused by deer feeding in the first year. Unfortunately, alfalfa in all treatments was winterkilled before the 1997-growing season leaving the long-term effect of deer feeding on stand persistence undocumented.

\section{Forage Quality:}

In general, $\mathrm{CP}, \mathrm{ADF}$, and NDF content of the forage were not affected by deer feeding (data not shown). This was unexpected considering the selective grazing of alfalfa from the unprotected plots. However, the relatively frequent harvest schedule used in this research probably minimized differences in quality that may have been observed with less frequent harvests (i.e. more mature forages). Over all treatments, forage quality between seeding treatments was

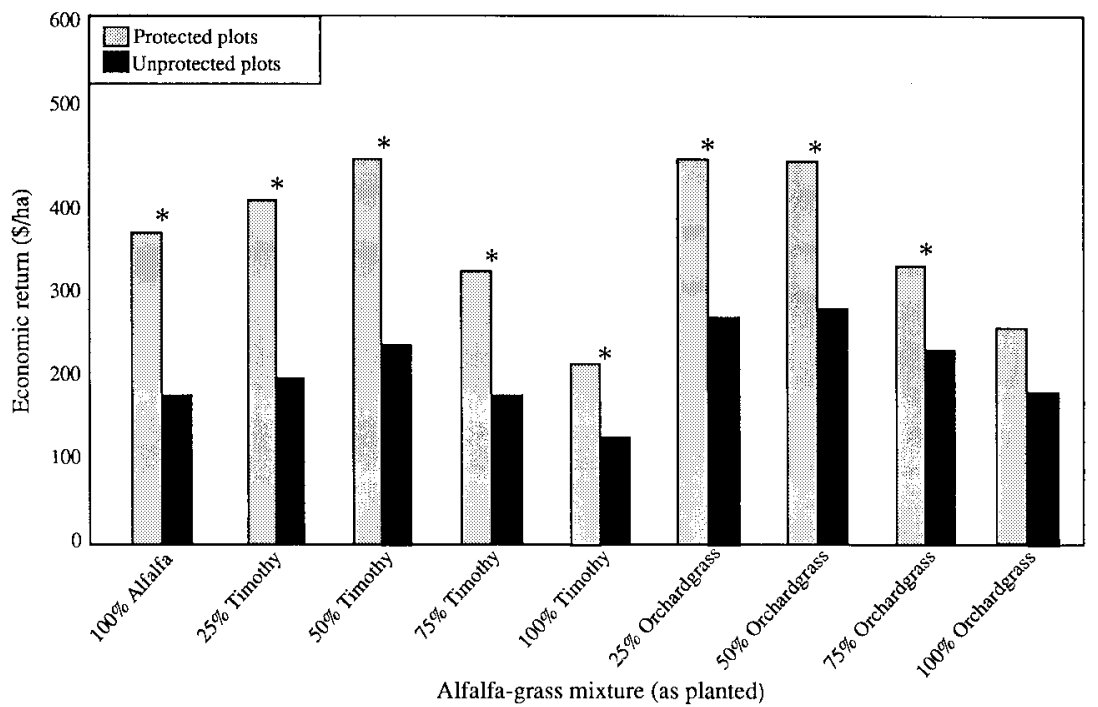

Fig. 2. Economic return from pure stands and mixtures of forages that were protected or unprotected from deer feeding. Values are the mean of 2 locations over 2 years. Protected or unprotected means with an * are different at the 0.05 level. pure alfalfa $>$ alfalfa-timothy mixtures>alfalfa-orchardgrass mixtures.

\section{Net Return:}

Deer feeding on forages resulted in average economic losses of $\$ 152 \mathrm{ha}^{-1}$ (Fig. 2). The economic impact associated with deer feeding in this study was similar to those reported by Palmer et al. (1982). Averaged over all unprotected treatments, mixtures containing orchardgrass had $\$ 59 \mathrm{ha}^{-1}$ greater economic returns than mixtures containing timothy. This result is in direct response to the increased deer feeding on timothy mixtures. Under situations where deer had access to forage crops, seeding mixtures of alfalfa with $50 \%$ timothy or 25 to $75 \%$ orchardgrass gave the greatest economic returns. The apparent discrepancy between high forage yield and low economic returns with pure orchardgrass is due to its lower forage quality and lower forage value relative to other treatments.

\section{Conclusions}

Deer feeding caused significant yield and economic losses to alfalfa and alfalfa-grass mixtures. Deer selectively grazed alfalfa out of alfalfa-grass mixtures and preferred timothy over orchardgrass. Orchardgrass alone or seeded in mixture at greater than $50 \%$ minimized deer feeding and resulted in the greatest forage yields. However, greatest economic return resulted with seeding mixtures containing 50\% timothy or 25 to $75 \%$ orchardgrass.

The results of this research indicate that farmers who experience deer damage to their alfalfa and can not exclude the deer with fencing may be able to minimize the negative effect of deer feeding by seeding alfalfa-grass mixtures. Dairy farmers who can realize increased income (milk production) from high quality forages should consider seeding alfalfa mixed with 50\% timothy or 25 to $50 \%$ orchardgrass. These treatments produced maximum economic returns based on yield and forage quality. On the other-hand, farmers with livestock that do not require high quality forage (e.g. brood cows) should plant pure orchardgrass for maximum forage yield. 


\section{References}

Andelt, W.F., K.P. Burnham, and J.A. Manning. 1991. Relative effectiveness of repellents for reducing mule deer damage. J. Wildl. Manage. 55:341-347.

English, P.S. and W.C. Bramble. 1949. Kill 'em?-Starve 'em?-Feed 'em? Deer eat best forage they can find. p. 7-8. In: Science for the farmer. Pennsylvania Agr. Exp. Sta.

George, J.L., R.G. Wingard, and W.L. Palmer. 1983. Penn State's "five-alive" deer fence. Amer. Forests. 89:30-32.

Goering, J.K. and P.J. Van Soest. 1970. Forage fiber analysis: Apparatus, reagents, procedures, and some applications. USDA Agr. Handb. 379. U.S. Gov. Print. Office, Washington, D.C.

Hall, M.H. and J.W. Eckert. 1992. Seeding year harvest management of red clover. J. Prod. Agr. 5:52-57.

Hall, M.H. and L.E. Marshall. 1996. Harvest management to maximize dry matter and nutrient yield, and economic return of red clover. J. Prod. Agr. 9:407-410.
Hunt, W.F. and R.J.M. Hay. 1989. Alternative pasture species for deer production in the Waikato. p. 31-33. In: Proceeding of the Ruakura Deer Industry conference. Hamilton, New Zealand.

Kalu, B.A. and G.W. Fic. 1981. Quantifying morphological development of alfalfa for studies of herbage quality. Crop Sci. 21:267-271.

Kosack, J. 1996. 1996-97 Big game forecast. Pennsylvania Game News. 67(11):4-8

Linn, J. and N.P. Martin. 1985. Using forage tests results in dairy rations. Minnesota Agr. Exp. Serv. AG-FS-2637.

Palmer, W.L., G.M. Kelly, and J.L. George. 1982. Alfalfa losses to whitetailed deer. Wildl. Soc. Bull. 10:259-261.

Pennsylvania Agricultural Statistics Service. 1997. Statistical Summary and Annual Report. Report 121. Pennsylvania Agr. Statist. Serv., Harrisburg, Penn. p. 90. Schumacher, J. 1997. Clash over deer control. Centre Daily Times. 9 March, p. 10A.
Shenk, J.S. and M.O. Westerhaus. 1994. The application of near infrared reflectance spectroscopy (NIRS) to forage analysis. p. 406-409. In: G.C. Fahey (ed.). Forage quality, evaluation, and utilization. ASA, CSSA, and SSSA. Madison, Wisc.

Shope, W.K. 1970. Behavioral characteristics of the white-tailed deer (Odocoileus virginianus) in relations to crop damage in Centre County, PA. M.S. Thesis. The Pennsylvania State Univ., University Park, Penn.

Thomas, D.W. 1954. An economic analysis of deer damage to farm crops and income from deer hunters, Potter and Monroe Counties, Pennsylvania. Ph.D. Diss. The Pennsylvania State Univ., University, Park, Penn.

Vecellio, G.M., R.Y. Yahner, and G.L. Storm. 1994. Crop damage by deer at Gettysburg Park. Wildl. Soc. Bull. 22:89-93. 